\title{
Use of Internet Social Networks in Academic Environment
}

\section{Renáta Cenková}

renata.cenkova@upjs.sk

Section of Mass Media Studies

Department of Slovak Studies, Slavonic Philologies, and Communication Faculty of Arts

Pavol Jozef Šafárik

University in Košice, Košice, Slovak Republic

\section{William Steingartner}

Department of Computers and Informatics

Faculty of Electrical Engineering and Informatics

Technical university of Košice, Košice, Slovak Republic

william.steingartner@tuke.sk

\begin{abstract}
Numerous national and private Slovak universities and colleges are currently confronted with a state, where the offer of study programmes exceeds its demandstudents' interests. This paper describes reasons for this situation but mainly it points out the fact that the advent of information and communication technologies significantly intervened in different areas of life and all types of communication. The implementation of some tools of internet social networks in the academic environment is, therefore, essential. In addition to the theoretical background, the paper also includes case study related to the creation of a new Facebook profile \#MaŠtu, setting up specific online marketing key performance indicators (KPI) and monitoring them using both Facebook analytics metrics and the social networking tool for administration, ZoomSphere.
\end{abstract}

Keywords. Academic environment, Facebook analytics, Facebook page \#MaŠtu, information and communication technologies, internet social networks, ZoomSphere

\section{Introduction}

Communication changes associated with the use of digital data processing and telecommunication transmission, namely the emergence of information and communication technologies (ICT), have brought significant changes to the very nature of communication as well as to its research. The digitization of communication also carries a new social 
phenomenon with itself. The exponential growth of Internet access and ICT greatly influenced social, political, and economic processes worldwide. Besides that ICT used in education with purpose to improve student learning and to give better teaching methods using geometric visualization [1], it can be also used through social networks.

Information and Communication Technology and Social Networking Websites have become forces to figure within the task of information dissemination in the 21st Century. One of the most visible applications of social media is the building of a network for career development and education [2]. Although ICT and social media are conceptually different, they are tangled and inseparably connected and they converge when mobilized as resources for or employed as means in social change, a process that causes altering social patterns of society. Advances in ICT have proclaimed a major transformation in human communication, giving rise to new trends of media for social communication.

A basic issue in a social network is to identify the key persons within it. This is why different centrality measures have been found over the years [3]. Nowadays, social networks are becoming ubiquitous in an increasing rate throughout the world; they particularly attract the younger generation, becoming an inseparable part of their daily lives [4]. However, the most interesting aspect of ICT in social media is connected with learning.

A great proportion of social interactions have been transferred from face to face (personal) communication to the so-called "impersonal level" implemented through ICT. Percipients have become a part of the process of constructing information while being able to construct information and reality that matches their needs. The nature, extension, and popularity of ICT both quantitatively and qualitatively intervened in the original principles of the once-dominant communication paradigm. Changing the form of information inevitably affects its content. From today's perspective, digital technologies represent a field which is already very extensive and internally differentiated, yet very closely interrelated. Therefore, even in the context of school education, it is no longer possible to pursue the concept, where merely isolated skills are developed with the aim of mastering such individual computer programs that are expected to be encountered by the educated generation in their everyday life [5]. Researchers emphasize that in highly competitive and constantly changing business environment regardless of the professional orientation mix of technical, business, managerial and social skills give a huge advantage to all the students/employees as they will participate in the smart and sustainable solutions for everyone [6].

Current trends are directed from written and spoken speech to the visual representation of communication, favoring large pictures, photographs, distinctive headlines, and only a little information encoded in the text. The purpose of this fancy message is to achieve efficiency by using the effective way of representation (the highest number of impressions, likes, clicks, reactions, and dissemination of information, etc.). Co-modification of such messages is sophisticated, characterized primarily by informational immanence.

The paper is organized as follows: in Section 2, we present the theoretical background and motivation for our research. Section 3 is the core of this paper. Here we present a creation of the Facebook profile \#MaŠtu and its short history (sec. 3.1), a research 
methodology (sec. 3.2), setting the research goals (sec. 3.3), fulfilling the objectives (sec. 3.4) and in resulting part, comparison of selected key performance indicators (sec. 3.5). We finish our work with Conclusions.

\section{Theoretical Outcomes}

The advent of ICT significantly intervened in different areas of life and all types of communication, including marketing communication [7,8]. The number of internet users as well as the number of members of the virtual category, who need to share information, experience, products, etc. increases. It was, therefore, necessary to create new virtual social structures, most often by using so-called social networks. The term social network comes from sociology, although it has appeared in the scientific literature since the 19th century. Internet social networks are considered to be structures of nods that represent individuals, groups, organizations, etc. These nods are interconnected by mutual bonds, which may not necessarily be positive (friendship, partnership, common views, hobbies, etc.) but they can also carry elements of hatred, intolerance, etc. [9].

Marketing is a word made up of two parts consisting of the noun market and the suffix "ing", which means that it can be characterized as a continuous process of continuous operation in the market; and the market, which aims to satisfy the needs of customers in the target market. Kotler [10] defines it as a continuous social and managerial process through which individuals and groups satisfy their needs and wishes in the process of manufacturing and changing products or other values.

There are many goals of different marketing concepts and they can be diametrically different, but at least one has in common - an effort to increase profits. Internet has offered to the marketing a wider portfolio of options and tools that have enabled it not only to multiply (increase) the traditional carriers but also to create brand new platforms (tools) - among which we place social networks.

Social networks are an essential part of online marketing, even in the case of minimum or zero budget. Because of this financial inconvenience, we talk about beneficial informational, possibly advertising carriers used by organizations on a low budget, including academic institutions. Numerous national and private Slovak universities and colleges are currently confronted with a state, where the offer of study programmes exceeds its demand - number of students [11]. There are several causes that have caused this state: the outflow of students abroad, the low interest of students (especially) in technical fields, a high number of schools, etc. However, for one of the most outstanding reasons, we consider the fact that the population born in Slovakia in the years from 2000 to 2007, which have reached or will reach the age for higher education in the upcoming years, have been among the least numerous since the end of the World War II (1945). The number of children born in Slovakia in these years ranges from approximately 50000 to 54000 [12]. The number of colleges and faculties was 105 in the year 2016 [13].

Universities and colleges must react to this adverse demographic development, and they have to change their views on the promotion of individual fields of study, as well as 
on their target groups, whose members are the so-called Generation $Z$ (sometimes also Gen $\mathrm{Z}$ for short) from marketing designation - a common name for the most recent generation at the labor market. They were born in the years 1995-2015 and unlike previous generations - Generation Y, Generation X and baby boomers have grown up surrounded by digital environment since they were little. Members of Generation $\mathrm{Z}$ are characterized as highly connected, active use of communications and media technologies such as World Wide Web or YouTube. They are accustomed to collaborate, share and distribute images and information. Besides, they are often described as instant minded with faster life rhythm, and tending to be more individualistic and self-directed. With the advent of technological innovations, the Generation $\mathrm{Z}$ is constantly connected with their friends, peers, family, relatives and acquaintances [14]. Marketers see their strengths in creativity, that they know in, of how to build a community, in being strong personalities, who are technologically skilled, and with multitasking being typical for them - they use more media at once. On the contrary, they consider as their negatives: they do not know what is discretion, they cannot assess the situation, they lack some knowledge, skills and competences, they need guidance, they cannot concentrate on one thing for longer period, and their excessive confidence which is often on the borderline with arrogance puts them in trouble [15]. The representatives of Slovak Generation Z use smartphones, tablets, laptops, or PCs daily. They prefer screen communication, and social media is their domain. According to the survey of the GfK agency conducted in 2016 in Slovakia, the average teenager is active on up to five social networks, with up to $90 \%$ of respondents being daily on Facebook (FB). This is followed by Facebook Messenger, YouTube (61 \%), Instagram (24\%), Pokec ${ }^{1}$ (local social network, $19 \%$ ) etc. It is interesting that social networks such as Twitter, LinkedIn, etc. have not expanded considerably in Slovakia and especially in both Generations Y and Z. For more see the survey in [16].

\section{Creative and research part}

We consider the above-mentioned outputs from the exclusive survey GfK Slovakia as well as the data of the Statistical Office of the Slovak Republic ${ }^{2}$ as factors that show significant changes even in the field of an academic environment, requiring new approaches in the field of its promotion. The promotional activities of the mass media studies at Faculty of Arts (FA), UPJS in Košice have, so far, consisted of events intended for high school graduates - the so-called Open-day, PR articles, or scientific outputs of workplace employees in various media, and updates of information on www page. The change of demographic environment as well as ICT and media environment requires a new perspective on promotional activities. Therefore, we have carried out a SWOT analysis together with students at the beginning of the year 2018. Analysis of the strengths and weaknesses in the field and its promotional activities as well as the mapping of the competitive environment, and

1. pokec.azet.sk

2. wWw.statistics.sk 
the other mass media institutes in the Slovak Republic and other workplaces of Faculty of Arts at UPJS. Throughout the project, we compare and monitor our activities using the ZoomSphere analytical tool.

\subsection{Creating a Facebook profile \#MaŠtu}

The analysis resulted in the creation of an interactive Facebook profile \#MaŠtu (a very first photo of the profile is in Figure 1, left). Its name was created by students after brainstorming. It is an acronym for the name of the study field mass media, and at the same time, it has the meaning "You have a ..." for example, an interesting lecture etc. [17]. Similarly, students have created the logo of this profile (its the first version is in Figure 1, right). The page came into its existence on February 22nd, 2018, together with the first post on how students decided to create a page that presents everything that study in the mass media field involves. It was published on the same day at 2:08 PM with two photographs. On February 27, 2018, at 11:20 AM, profile picture and cover photo have been added.
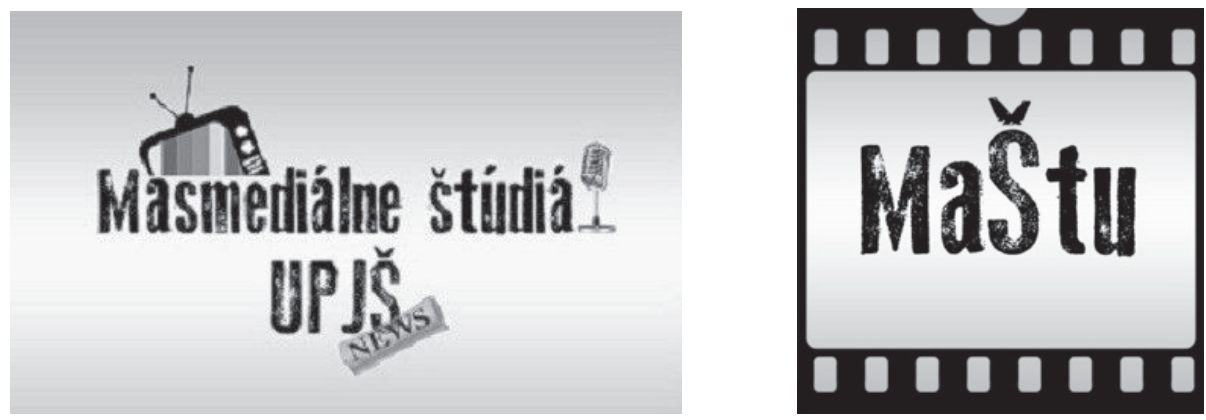

Figure 1. Cover photo of Facebook profile Mass media studies at UPJS (left), Profile photo (right)

The primary target group contains the fourth and third-year grade students of the secondary schools - potential future students in this field. The secondary group contains the current students, their relatives, and friends, graduates, teachers but also other interest groups, as well as the individual social groups of each member of the network/community. The aim is to form a community and to build loyalty to alma mater and the study field. The content consists of posts and statuses of high quality, with predominantly positive, neutral, or ideally funny content that respects the principles of Facebook formats (little text and more images, photos, gifs, and videos) [18].

Scholars praise social-networking tools for their capability to attract, motivate and engage students in meaningful communicative practice, content exchange, and collaboration. Communication is oriented toward students - current students speak to their peers using their "own language". They share experience and activities from lectures, seminars, free time activities, work in media, successes of school, field, students, and graduates of the study field, teachers, information from student life, life and events in Košice. They 
are guides around the city of Košice. They help the participants to become familiar with the campus. They recall the major anniversaries, international days, bring invitations and reports from interesting events, lectures, excursions, but also acknowledgments, and unveil backstage from the preparation of media communicants and their outputs. They support students who are preparing for the final state final examinations, represent successful graduates, and begin cooperation with other Facebook sites - e.g. Faculty of Arts of UPJS, contact with employers, sports clubs as HC Košice (ice hockey is a very popular sport; moreover, World championship in ice hockey took place in Bratislava and Košice in 2019, and the Slovak ice hockey representation was exclusively present itself in Košice).

\subsection{Methodology}

We were monitoring Facebook profile \#MaŠtu in the summer semester period from February 22 to June 16, 2018, both using the Facebook analytics metrics and using the ZoomSphere social networking tool ${ }^{3}$, which helps to analyze, monitor and evaluate activities in social networks from one place. It combines many functions in itself - e.g. the ability to publish posts to all pages not administrated by users, it offers on-line monitoring from social networks and Web resources, and comprehensive analysis for pages, which we administer. Then, it offers a comparative analysis of social networks, options to follow posts of any other pages, options for teamwork, scheduling of published activities, effective communication with contributors, etc.

Using this tool, we have evaluated individual Facebook metrics on both a weekly and monthly basis. Thanks to these ongoing analyzes, we were able to identify and optimize the most appropriate content and formats of our contributions as well as regularly monitor selected KPIs. It should be noted that we were aware of the fact when creating the content of our feed: The form is a complementary part to the content which should be dominant. When the form prevails the content in a creative process of a message, such a product could appeal to a customer but only when it comes to the first impression [19]. Because of the spatial narrowness, it is not possible to display all the data, so we can only see the most interesting ones.

For better clarity and illustrations, but also higher credibility of offered data, we bring in the next sections selected KPIs for the comparable period of 2019 - summer semester period from February 18 to June 14, 2019.

\subsection{Setting the objectives}

At the beginning of the project, which is still ongoing, we set out the basic objectives, the part of which is setting specific online marketing performance indicators - the so-called KPI - Key Performance Indicators.

Objective 1 : To find out what days and which times are the fans of Facebook page \#MaŠtu the most active.

3. WWW. zoomsphere.com 
Objective 2 : To reach the highest share on the "market" of similar study fields.

Objective 3 : To set up the profile to achieve the highest organic reach, viral reach, and engagement, i.e. to make most of the people to interact with our attitudes (compared to competing profiles).

Based on the research objectives, we formulate the research hypothesis:

By creating a Facebook profile of the Mass media studies program at UPJS in Košice and by regular interaction with fans, we activate applicants and increase their interest in this field of study.

\subsection{Fulfilling the objectives}

In this section, we will present individual discussions on the fulfillment of scientific objectives.

Ad Objective 1: To meet objective 1 we have established working student teams that have always administered the page within one week. Team members have regularly (at least three times a week) published news and interesting facts on the Facebook profile \#MaŠtu, while regularly monitoring it. They have always informed another working group about the results so they could use the information effectively.

Monitoring the activity of our fans during 17 weeks of the year 2018 led us to conclude that the most responses and interactions to posts were made in times between 8:00 and 9:00 PM, eventually, in the morning between 9:00 and 10:00 AM. Regarding the days of the week - we noted the greatest interest in \#MaŠtu activities on Sundays and Thursdays. We have monitored the impact but also the interaction of contributions. In the first two weeks, the page reached about 100 fans, with the average impact of each contribution around 600 views (at a maximum of 800). From February 22 until December 3, 2018, the page was liked by 71 fans, and on April 24, it has already been 322 fans. For the next few weeks, the number of fans has been rising only slowly: at the end of our reference period - on the June 16, they were 367.

The reference period (February 18 - June 14) for 2019 provided new data. At the beginning of the period under review on February 18, 2019, we had 446 fans. There were 570 at the end of the reporting period. During this period, we identified the time 7:00 - 8:00 AM as the most effective publishing times during the day; other times with high activity were 3:00 - 4:00 PM and 7:00 - 8:00 PM. Within days of the week, the highest activity was mainly on Mondays and Tuesdays.

Ad Objective 2: In addition to the creation and regular contribution to the Facebook profile \#MaŠtu we have also used other forms of promotion of this field. We have emailed all the high schools in the region of Košice and self-governing region of Prešov in Slovakia with a request to share this page. Information with the text on the creation of the Facebook profile \#MaŠtu was sent to 145 email addresses. We have asked educational 
institutions to share our page on their sites, thus assuming that thanks to this synergy effect, our market share will increase. At the time of our request, only three secondary schools (the Hotel Academy Bastion in Prešov, High school Giraltovce, and the Business Academy in Poprad) were granted, representing only $2.07 \%$ of all the asked participants. Later, our profile impressed other pages too - e.g. the student board of Faculty of Arts at UPJS, Pavol Josef Šafárik University in Košice, magazine Univerzál, the television channel of the university UniTV, hockey club HC Košice, etc. Thus the possibility of outreach, interaction, and engagement rate (ER) of our Facebook page greatly increased. We have identified two rounds of competing groups for \#MaŠtu. The first round consists of other media workplaces and similar study fields in the Slovak Republic - there are eight institutions, whose activity has been observed: the largest institution is the Faculty of Mass Media Communication, University of Ss. Cyril and Methodius in Trnava, which also has the largest market share. Then, the following are:

- Faculty of Commerce, the University of Economics in Bratislava,

- Institute of Slovak Studies and Media Studies, University of Prešov,

- Department of Marketing Communication, Comenius University in Bratislava,

- Department of Mass media communication, Constantine the Philosopher University in Nitra,

- Media Academy Bratislava,

- Department of Journalism, Constantine the Philosopher University in Nitra,

- Department of Journalism, Catholic University in Ružomberok,

- Mass media studies, UPJS in Košice.

Table 1 shows the results for the period from February 22 to June 16, 2018. Even though we have reached the lowest number of fans on the "market" (Fan's Trend) (2.2 $\%$ ), which is due to the fact that we came to market with a significant delay over the already established and entrenched profile, many current studies say that this indicator is not considered important along Facebook metrics. Some advertising agencies even claim that the so-called "page like" campaigns are ineffective [20].

Table 2 shows that we increased our market share to $3.4 \%$ (in compare to $2.2 \%$ in the year before) over the reporting period. We stayed in the last place but closely followed other domestic institutions.

We consider other institutions (departments) of the Faculty of Arts of UPJS in Košice to be the second competitive range. In this case, we have increased our market share in a couple of weeks, even in terms of the number of fans. Among thirteen workplaces we have reached $9.3 \%$ of market share (Table 3 ), which led us to the fifth place compared to other twelve departments - Department of history, Department of British and 


\begin{tabular}{|l|r|r|r|r|}
\hline & Actual & Share & Previous & Difference \\
\hline Total & 16750 & $100 \%$ & 12198 & $4.552(37 \%)$ \\
\hline $\begin{array}{l}\text { Faculty of Mass Media Comm., } \\
\text { Univ. of Ss. Cyril and Methodius } \\
\text { in Trnava }\end{array}$ & 7016 & $41.9 \%$ & 6940 & $76(1 \%)$ \\
\hline $\begin{array}{l}\text { Faculty of Commerce, University } \\
\text { of Economics in Bratislava }\end{array}$ & 2831 & $16.9 \%$ & 2818 & $13(0 \%)$ \\
\hline $\begin{array}{l}\text { Institute of Slovak Studies and Me- } \\
\text { dia Studies, University of Prešov }\end{array}$ & 1654 & $9.9 \%$ & & $1654(100 \%)$ \\
\hline $\begin{array}{l}\text { Department of Marketing Comm., } \\
\text { Comenius University in Bratislava }\end{array}$ & 1309 & $7.8 \%$ & 1285 & $24(2 \%)$ \\
\hline $\begin{array}{l}\text { Department of Mass media comm., } \\
\text { Constantine the Philosopher Univ. } \\
\text { in Nitra }\end{array}$ & 174 & $7 \%$ & 1155 & $19(2 \%)$ \\
\hline Media Academy Bratislava & 1153 & $6.9 \%$ & & $1153(100 \%)$ \\
\hline $\begin{array}{l}\text { Department of Journalism, Con- } \\
\text { stantine the Philosopher Univ. in } \\
\text { Nitra }\end{array}$ & 721 & $4.3 \%$ & & $721(100 \%)$ \\
\hline $\begin{array}{l}\text { Department of Journalism, Catholic } \\
\text { University in Ružomberok }\end{array}$ & 528 & $3.2 \%$ & & $528(100 \%)$ \\
\hline $\begin{array}{l}\text { Mass media studies, UPJS in } \\
\text { Košice }\end{array}$ & 364 & $2.2 \%$ & & $364(100 \%)$ \\
\hline
\end{tabular}

Table 1. Market share by fans of other mass media institutions in terms of the number of fans during the reference period from February 22 to June 16, 2018

American studies, Department of Political Science, Department of Psychology, Department of Philosophy and History of Philosophy, English language and French language for European Institutions, Department of Slovak Studies, Slavonic Philologies, and Communication, Department of Pedagogical Psychology and Health Psychology, Department of Social Work, Department of Applied Ethics, Department of German studies, Department of Classical Philology.

Both tables - Table 3 and Table 4 present a comparison of this parameter between the Department of Mass Media studies at UPJS in Košice and other (selected) institutions of Faculty of Arts of UPJS, in both years.

In this competitive range, we managed to reach almost $12.2 \%$ share in the monitored period of 2019, which took us to third place.

Taking into account the current distribution of forces in both competing ranges (the length of the existence of workplace, the length of the existence of profile, the number of students and graduates, the number of profile fans, etc.), we believe that we will manage 


\begin{tabular}{|l|r|r|r|r|}
\hline & Actual & Share & Previous & Difference \\
\hline Total & 16673 & $100 \%$ & 16380 & $293(2 \%)$ \\
\hline $\begin{array}{l}\text { Faculty of Mass Media Comm., } \\
\text { Univ. of Ss. Cyril and Methodius } \\
\text { in Trnava }\end{array}$ & 7510 & $45 \%$ & 7434 & $76(1 \%)$ \\
\hline $\begin{array}{l}\text { Faculty of Commerce, University } \\
\text { of Economics in Bratislava }\end{array}$ & 2938 & $17.6 \%$ & 2920 & $18(0.6 \%)$ \\
\hline $\begin{array}{l}\text { Institute of Slovak Studies and Me- } \\
\text { dia Studies, University of Prešov }\end{array}$ & 1702 & $10.2 \%$ & 1703 & $-1(0.1 \%)$ \\
\hline $\begin{array}{l}\text { Department of Marketing Comm., } \\
\text { Comenius University in Bratislava }\end{array}$ & 1378 & $8.3 \%$ & 1351 & $27(2 \%)$ \\
\hline $\begin{array}{l}\text { Department of Mass media comm., } \\
\text { Constantine the Philosopher Univ. } \\
\text { in Nitra }\end{array}$ & 1256 & $7.5 \%$ & 1229 & $27(2 \%)$ \\
\hline $\begin{array}{l}\text { Department of Journalism, Con- } \\
\text { stantine the Philosopher Univ. in } \\
\text { Nitra }\end{array}$ & 743 & $4.5 \%$ & 736 & $7(1.0 \%)$ \\
\hline $\begin{array}{l}\text { Department of Journalism, Catholic } \\
\text { University in Ružomberok }\end{array}$ & 576 & $3.5 \%$ & 562 & $14(2 \%)$ \\
\hline $\begin{array}{l}\text { Mass media studies, UPJS in } \\
\text { Košice }\end{array}$ & 570 & $3.4 \%$ & 445 & $125(28 \%)$ \\
\hline
\end{tabular}

Table 2. Market share by fans of other mass media institutions in terms of the number of fans during the reference period from February 18 to June 14, 2019

\begin{tabular}{|l|r|r|r|r|}
\hline & Actual & Share & Previous & Difference \\
\hline Total & 3920 & $100 \%$ & 0 & $3920(100 \%)$ \\
\hline Department of history & 831 & $21.2 \%$ & & $831(100 \%)$ \\
\hline $\begin{array}{l}\text { Department of British and Ameri- } \\
\text { can studies }\end{array}$ & 674 & $17.2 \%$ & & $674(100 \%)$ \\
\hline Department of Political Science & 578 & $14.7 \%$ & & $578(100 \%)$ \\
\hline Department of Psychology & 471 & $12.0 \%$ & & $471(100 \%)$ \\
\hline Mass media studies & 364 & $9.3 \%$ & & $364(100 \%)$ \\
\hline
\end{tabular}

Table 3. Share in the "market by fans" of other (selected) institutions of Faculty of Arts of UPJS in terms of the number of fans during the reference period from February 22 to June 16, 2018

to fulfill Objective 2 in the upcoming time.

Ad Objective 3: We realize that we could use several analytic tools for analysis, but ZoomSphere is available in our institute under the license for free as a learning resource for our students. ZoomSphere as a social media tool offers a large number of analyses - 


\begin{tabular}{|l|r|r|r|r|}
\hline & Actual & Share & Previous & Difference \\
\hline Total & 4666 & $100 \%$ & 4444 & $222(5 \%)$ \\
\hline Department of history & 928 & $19.9 \%$ & 910 & $18(2 \%)$ \\
\hline $\begin{array}{l}\text { Department of British and Ameri- } \\
\text { can studies }\end{array}$ & 763 & $16.4 \%$ & 741 & $22(3 \%)$ \\
\hline Department of Political Science & 609 & $13.1 \%$ & 600 & $9(2 \%)$ \\
\hline Mass media studies & 570 & $12.2 \%$ & 445 & $125(28 \%)$ \\
\hline
\end{tabular}

Table 4. Share in the "market by fans" of other (selected) institutions of Faculty of Arts of UPJS in terms of the number of fans during the reference period from February 18 to June 14, 2019

in addition to the number of fans (page fans) it can detect where they come from, or where they operate (page fans by city), examines what is their language composition (page fans local), finds out when - at what time and what date they are online (Page fans online and Page fans online per day), even every week, identifies the most active fans (the most active users), and identifies posts with the highest number of likes. Part of fulfilling the Objective 3 was also to monitor the Page Interactions (sometimes the parameter also refers to as Account Interactions).

\begin{tabular}{|l|r|r|r|r|}
\hline & Actual & Share & Previous & Difference \\
\hline Mass media studies, Košice & 2434 & $36.7 \%$ & 0 & $2434(100 \%)$ \\
\hline $\begin{array}{l}\text { Faculty of Mass Media Comm., } \\
\text { Univ. of Ss. Cyril and Methodius } \\
\text { in Trnava }\end{array}$ & 1747 & $26.3 \%$ & 1328 & $419(32 \%)$ \\
\hline $\begin{array}{l}\text { Department of Journalism, Con- } \\
\text { stantine the Philosopher Univ. in } \\
\text { Nitra }\end{array}$ & 692 & $9.5 \%$ & 51 & $578(1.133 \%)$ \\
\hline $\begin{array}{l}\text { Faculty of Commerce, University } \\
\text { of Economics in Bratislava }\end{array}$ & 601 & $9.0 \%$ & 107 & $494(462 \%)$ \\
\hline
\end{tabular}

Table 5. Page interactions in the reference period from February 22 to June 6, 2018 (selected institutions)

Within the total number of all interactions during the reference period, the profile of mass media studies in Košice has reached up to 2434 interactions (likes, shares, comments, etc. representing $36.7 \%$ of market share (Table 5). This result is even more satisfying because the profile has reached the primacy of the competing schools, whose profiles have existed much longer.

During the reporting period of 2019 we achieved 2055 interactions (Table 6), which is a slight decrease compared to 2018, which in comparison with other mass media institutes in Slovakia took us to the second place, but only with $14.3 \%$ market share, as in this 


\begin{tabular}{|l|r|r|r|r|}
\hline & Actual & Share & Previous & Difference \\
\hline $\begin{array}{l}\text { Faculty of Mass Media Comm., } \\
\text { Univ. of Ss. Cyril and Methodius } \\
\text { in Trnava }\end{array}$ & 816 & $61.4 \%$ & 5615 & $3201(57 \%)$ \\
\hline $\begin{array}{l}\text { Mass media studies, UPJS in } \\
\text { Košice }\end{array}$ & 2055 & $14.3 \%$ & 802 & $1253(156 \%)$ \\
\hline $\begin{array}{l}\text { Faculty of Commerce, University } \\
\text { of Economics in Bratislava }\end{array}$ & 872 & $6.1 \%$ & 262 & $610(233 \%)$ \\
\hline $\begin{array}{l}\text { Department of Mass media comm., } \\
\text { Constantine the Philosopher Univ. } \\
\text { in Nitra }\end{array}$ & 751 & $5.2 \%$ & 126 & $625(496 \%)$ \\
\hline $\begin{array}{l}\text { Institute of Slovak Studies and Me- } \\
\text { dia Studies, University of Prešov }\end{array}$ & 560 & $3.9 \%$ & 308 & $252(82 \%)$ \\
\hline $\begin{array}{l}\text { Department of Marketing Comm., } \\
\text { Comenius University in Bratislava }\end{array}$ & 475 & $3.3 \%$ & 9 & $466(5178 \%)$ \\
\hline $\begin{array}{l}\text { Department of Journalism, Catholic } \\
\text { University in Ružomberok }\end{array}$ & 419 & $2.9 \%$ & 76 & $343(451 \%)$ \\
\hline $\begin{array}{l}\text { Department of Journalism, Con- } \\
\text { stantine the Philosopher Univ. in } \\
\text { Nitra }\end{array}$ & 413 & $2.9 \%$ & 92 & $321(349 \%)$ \\
\hline
\end{tabular}

Table 6. Page Interactions in the reference period from February 18 to June 14, 2019

parameter strengthened the Faculty of Mass Media Communication, University of Ss. Cyril and Methodius in Trnava (61.4\%).

In the framework of the investigated Page Interactions parameter, thus all the interactions during the investigated period, we compared the profile \#MaŠtu to other workplaces of Faculty of Arts of UPJS - even here we took the first place. The profile reached 48.8 $\%$ of market share, which represented 2434 different interactions. The second was the Department of History that reached only $16.6 \%-828$ interactions (Table 7).

The Social media tool ZoomSphere offers various KPIs, for instance: the number of views - clicks on the page (page views), the number of external accesses to the page (mostly from www.google.com), the number of interactions (called engagement), etc.

However, some marketers argue that engagement or reach is overrated. Most people want to increase engagement, thus having more likes and feedback on the news feed, but engagement can be misleading and certainly not a marker of brand values. To increase reach and engagement, we just need to make a competition, but that does not create a relationship between the brand and the customer. Currently, parameter called engagement rate $(E R)$ is considered to be a KPI with the highest value for the brand and building awareness of it through social networks, which is a proportion of all engaged users $(E U)$ - the number of unique users who, in any way, clicked on the content of the page but didn't 


\begin{tabular}{|l|r|r|r|r|}
\hline & Actual & Share & Previous & Difference \\
\hline Mass media studies & 2434 & $48.8 \%$ & 0 & $2434(100 \%)$ \\
\hline Department of history & 828 & $16.6 \%$ & 519 & $309(60 \%)$ \\
\hline Department of Political Science & 779 & $15.6 \%$ & 712 & $67(9 \%)$ \\
\hline $\begin{array}{l}\text { Department of British and Ameri- } \\
\text { can studies }\end{array}$ & 458 & $9.2 \%$ & 360 & $98(27 \%)$ \\
\hline Department of Psychology & 338 & $6.8 \%$ & 143 & $195(136 \%)$ \\
\hline $\begin{array}{l}\text { English language and French lan- } \\
\text { guage for European Institutions }\end{array}$ & 83 & $1.7 \%$ & 50 & $33(66 \%)$ \\
\hline Department of German studies & 25 & $0.5 \%$ & 32 & $-7(22 \%)$ \\
\hline $\begin{array}{l}\text { Department of Pedagogical Psy- } \\
\text { chology and Health Psychology }\end{array}$ & 21 & $0.42 \%$ & 73 & $-52(71 \%)$ \\
\hline $\begin{array}{l}\text { Department of Philosophy and His- } \\
\text { tory of Philosophy }\end{array}$ & 7 & $0.14 \%$ & 7 & $0(0 \%)$ \\
\hline Department of Applied Ethics & 7 & $0.14 \%$ & 25 & $-18(72 \%)$ \\
\hline Department of Classical Philology & 4 & $0.08 \%$ & 3 & $1(33 \%)$ \\
\hline Department of Social Work & 0 & $0 \%$ & 3 & $-3(100 \%)$ \\
\hline
\end{tabular}

Table 7. Page interactions in the reference period of February 22 to June 16, 2018 (departments of FA UPJS)

mark to like it, share it, nor comment (if they did, there was already a story created) the split reach, thus the number of people who have seen particular post and multiplied by one hundred:

$$
E R=E U \times 100 .
$$

ZoomSphere ER offers a parameter The average number of interactions per fan in its portfolio - it obtains its value by the number of interactions divided by fans and multiplied by one hundred. This KPI is one the most important within the following Facebook pages because it builds brand awareness and interaction among users and Facebook page. The resulting engagement rate depends primarily on published posts, on their form but also frequency. Therefore, it is necessary to publish with some periodicity. And just in this parameter, Facebook profile \#MaŠtu was the highest during this reference period.

In this key parameter, the Facebook profile \#MaŠtu took the first place. It formed up to $82 \%$ of the total share and the average number of interactions per fan reached number 10.421. Fans of other monitored pages were less active (Table 8).

In terms of impact, the most successful posts were made during the reference period: International Day of Teachers (organic reach (OR) 1112) 269, about the successful graduate (OR 1177) 410, photo from the teaching of the subject Acoustic-Auditive Communication (OR 1245) 509, Earth Day (OR 2839) 162, Cooperation with HC Košice (OR 6143) 834 , We realized that the results presented are changing every day, and it is es- 


\begin{tabular}{|l|r|r|r|r|}
\hline & $\begin{array}{r}\text { Actual } \\
\text { AVG }\end{array}$ & Share & $\begin{array}{r}\text { Previous } \\
\text { AVG }\end{array}$ & Difference \\
\hline Mass media studies, Košice & 10.421 & $82 \%$ & 0.000 & $100 \%$ \\
\hline $\begin{array}{l}\text { Department of Journalism, Con- } \\
\text { stantine the Philosopher Univ. in } \\
\text { Nitra }\end{array}$ & 0.778 & $6.1 \%$ & 0.062 & $1164 \%$ \\
\hline $\begin{array}{l}\text { Department of Journalism, Catholic } \\
\text { University in Ružomberok }\end{array}$ & 0.519 & $4.1 \%$ & 0.170 & $206 \%$ \\
\hline $\begin{array}{l}\text { Department of Mass media comm., } \\
\text { Constantine the Philosopher Univ. } \\
\text { in Nitra }\end{array}$ & 0.240 & $1.9 \%$ & 0.156 & $54 \%$ \\
\hline
\end{tabular}

Table 8. Average number of interactions per fan for the period from Feb. 22 to June 16, 2018

sential to develop a large number of effort and activities to maintain the highest position possible and to impress its "fan" - a potential future student.

\begin{tabular}{|l|r|r|r|r|}
\hline & $\begin{array}{r}\text { Actual } \\
\text { AVG }\end{array}$ & Share & $\begin{array}{r}\text { Previous } \\
\text { AVG }\end{array}$ & Difference \\
\hline $\begin{array}{l}\text { Mass media studies, UPJS in } \\
\text { Košice }\end{array}$ & 3.402 & $49.6 \%$ & 1.559 & $118 \%$ \\
\hline $\begin{array}{l}\text { Faculty of Mass Media Comm., } \\
\text { Univ. of Ss. Cyril and Methodius } \\
\text { in Trnava }\end{array}$ & 1.005 & $14.7 \%$ & 0.652 & $54 \%$ \\
\hline $\begin{array}{l}\text { Department of Journalism, Catholic } \\
\text { University in Ružomberok }\end{array}$ & 0.626 & $9.1 \%$ & 0.116 & $440 \%$ \\
\hline $\begin{array}{l}\text { Department of Mass media comm., } \\
\text { Constantine the Philosopher Univ. } \\
\text { in Nitra }\end{array}$ & 0.513 & $7.5 \%$ & 0.088 & $480 \%$ \\
\hline $\begin{array}{l}\text { Department of Journalism, Con- } \\
\text { stantine the Philosopher Univ. in } \\
\text { Nitra }\end{array}$ & 0.476 & $6.9 \%$ & 0.107 & $345 \%$ \\
\hline $\begin{array}{l}\text { Department of Marketing Comm., } \\
\text { Comenius University in Bratislava }\end{array}$ & 0.298 & $4.3 \%$ & 0.006 & $5085 \%$ \\
\hline $\begin{array}{l}\text { Institute of Slovak Studies and Me- } \\
\text { dia Studies, University of Prešov }\end{array}$ & 0.281 & $4.1 \%$ & 0.156 & $80 \%$ \\
\hline $\begin{array}{l}\text { Faculty of Commerce, University } \\
\text { of Economics in Bratislava }\end{array}$ & 0.254 & $3.7 \%$ & 0.077 & $231 \%$ \\
\hline
\end{tabular}

Table 9. Average number of interactions per fan for the reference period from February 18 to June 14, 2019 
Even in 2019, our Facebook profile retained the lead in this parameter. The average number of interactions per fan reached the number 3.402, which is 49.6 percent market share (Table 9). The second one was again Faculty of Mass Media Comm., Univ. of Ss. Cyril and Methodius in Trnava with 1.005 fans (14.7\%).

To verify the research hypothesis, we will compare selected KPIs within the first competitive range (other mass media institutions in Slovakia) for the years 2018 and 2019. We will compare the data with the official data from the Study Department at the Faculty of Arts of the UPJS in Košice and the number of candidates admitted studying in the years 2017, 2018 and 2019. Based on these data, we can see the year-on-year development of students' interest in this field of study, and we can assume that one of the effective marketing tools is a managed communication through social networks (mainly Facebook and currently Instagram, as well).

\begin{tabular}{|l|r|r|}
\hline Institute & $\mathbf{2 0 1 8}$ & $\mathbf{2 0 1 9}$ \\
\hline $\begin{array}{l}\text { Faculty of Mass Media Comm., Univ. of Ss. Cyril and Methodius } \\
\text { in Trnava }\end{array}$ & 7016 & 7510 \\
\hline Faculty of Commerce, University of Economics in Bratislava & 2831 & 2938 \\
\hline Institute of Slovak Studies and Media Studies, University of Prešov & 1654 & 1702 \\
\hline $\begin{array}{l}\text { Department of Marketing Comm., Comenius University in } \\
\text { Bratislava }\end{array}$ & 1309 & 1378 \\
\hline $\begin{array}{l}\text { Department of Mass media comm., Constantine the Philosopher } \\
\text { Univ. in Nitra }\end{array}$ & 1174 & 1256 \\
\hline Media Academy Bratislava & 1153 & 0 \\
\hline $\begin{array}{l}\text { Department of Journalism, Constantine the Philosopher Univ. in } \\
\text { Nitra }\end{array}$ & 721 & 743 \\
\hline Department of Journalism, Catholic University in Ružomberok & 528 & 576 \\
\hline Mass media studies, UPJS in Košice & 364 & 570 \\
\hline
\end{tabular}

Table 10. Trend of fans in years 2018 and 2019

\subsection{Comparison of selected KPIs}

In this section, we present the comparison of selected KPIs for the years 2018 and 2019 in the segment of \#MaŠtu and other mass media institutions in Slovakia. We focused on the following indicators:

- trend of fans (values are listed in Table 10 and depicted in chart in Figure 2);

- number of interactions with web page (Table 11, chart in Figure 3);

- average number of interactions per fan (Table 12, chart in Figure 4);

- numbers of applications, of admissions and number of applicants for undergraduate mass media studies FA UPJS in Košice (Table 13, chart in Figure 5). 


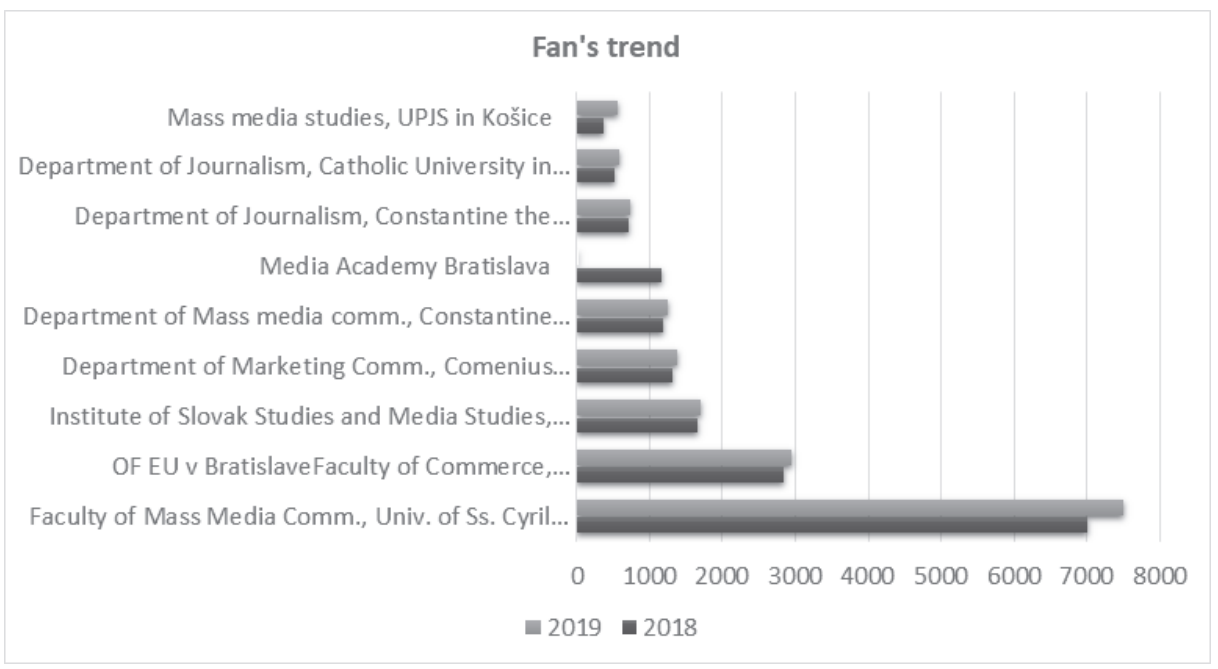

Figure 2. Fan's Trend

\begin{tabular}{|l|r|r|}
\hline Institute & $\mathbf{2 0 1 8}$ & $\mathbf{2 0 1 9}$ \\
\hline $\begin{array}{l}\text { Faculty of Mass Media Comm., Univ. of Ss. Cyril and Methodius } \\
\text { in Trnava }\end{array}$ & 1747 & 8816 \\
\hline Faculty of Commerce, University of Economics in Bratislava & 601 & 872 \\
\hline Institute of Slovak Studies and Media Studies, University of Prešov & 337 & 560 \\
\hline $\begin{array}{l}\text { Department of Marketing Comm., Comenius University in } \\
\text { Bratislava }\end{array}$ & 259 & 475 \\
\hline $\begin{array}{l}\text { Department of Mass media comm., Constantine the Philosopher } \\
\text { Univ. in Nitra }\end{array}$ & 322 & 751 \\
\hline $\begin{array}{l}\text { Department of Journalism, Constantine the Philosopher Univ. in } \\
\text { Nitra }\end{array}$ & 629 & 413 \\
\hline Department of Journalism, Catholic University in Ružomberok & 312 & 419 \\
\hline Mass media studies, UPJS in Košice & 2434 & 2055 \\
\hline
\end{tabular}

Table 11. Page interactions 


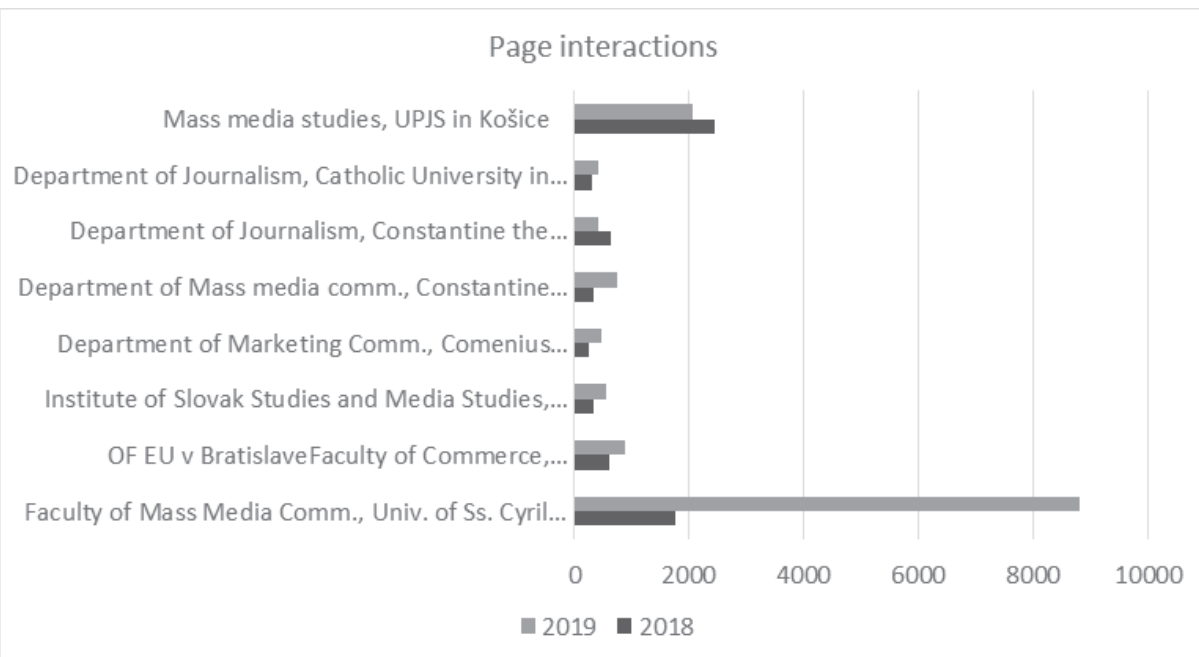

Figure 3. Page Interactions

\begin{tabular}{|l|r|r|}
\hline Institute & $\mathbf{2 0 1 8}$ & $\mathbf{2 0 1 9}$ \\
\hline $\begin{array}{l}\text { Faculty of Mass Media Comm., Univ. of Ss. Cyril and Methodius } \\
\text { in Trnava }\end{array}$ & 0.22 & 1.01 \\
\hline Faculty of Commerce, University of Economics in Bratislava & 0.18 & 0.25 \\
\hline Institute of Slovak Studies and Media Studies, University of Prešov & 0.18 & 0.28 \\
\hline $\begin{array}{l}\text { Department of Marketing Comm., Comenius University in } \\
\text { Bratislava }\end{array}$ & 0.17 & 0.30 \\
\hline $\begin{array}{l}\text { Department of Mass media comm., Constantine the Philosopher } \\
\text { Univ. in Nitra }\end{array}$ & 0.24 & 0.51 \\
\hline $\begin{array}{l}\text { Department of Journalism, Constantine the Philosopher Univ. in } \\
\text { Nitra }\end{array}$ & 0.78 & 0.48 \\
\hline Department of Journalism, Catholic University in Ružomberok & 0.52 & 0.63 \\
\hline Mass media studies, UPJS in Košice & 10.42 & 3.40 \\
\hline
\end{tabular}

Table 12. The average number of interactions per fan

\begin{tabular}{llll}
\hline Year & $\begin{array}{l}\text { Number of } \\
\text { applications }\end{array}$ & $\begin{array}{l}\text { Number } \\
\text { admitted }\end{array}$ & $\begin{array}{l}\text { Number of } \\
\text { registrations }\end{array}$ \\
\hline 2017 & 63 & 49 & 36 \\
\hline 2018 & 90 & 56 & 40 \\
\hline 2019 & 94 & 59 & 44 \\
\hline
\end{tabular}

Table 13. Numbers of applications, of admissions and number of applicants for mass media studies FA UPJS in Košice (undergraduate) 


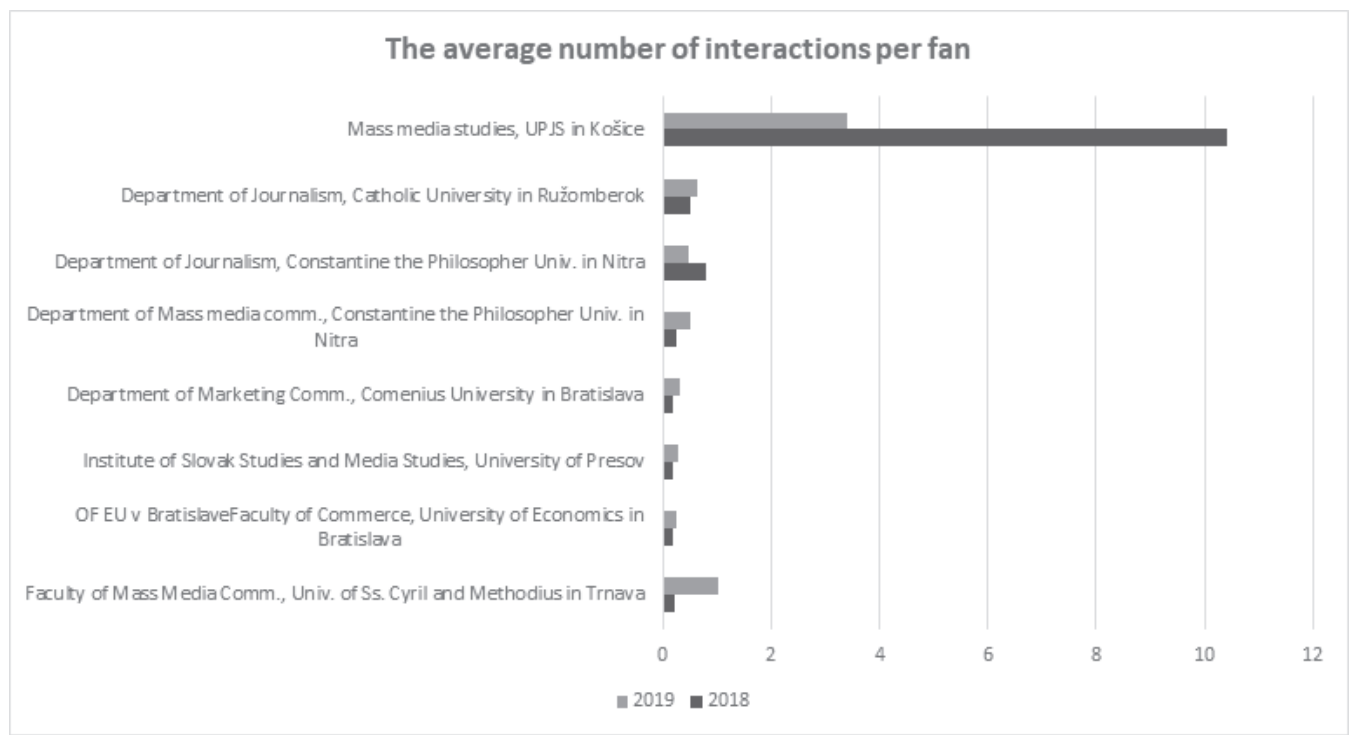

Figure 4. The average number of interactions per fan

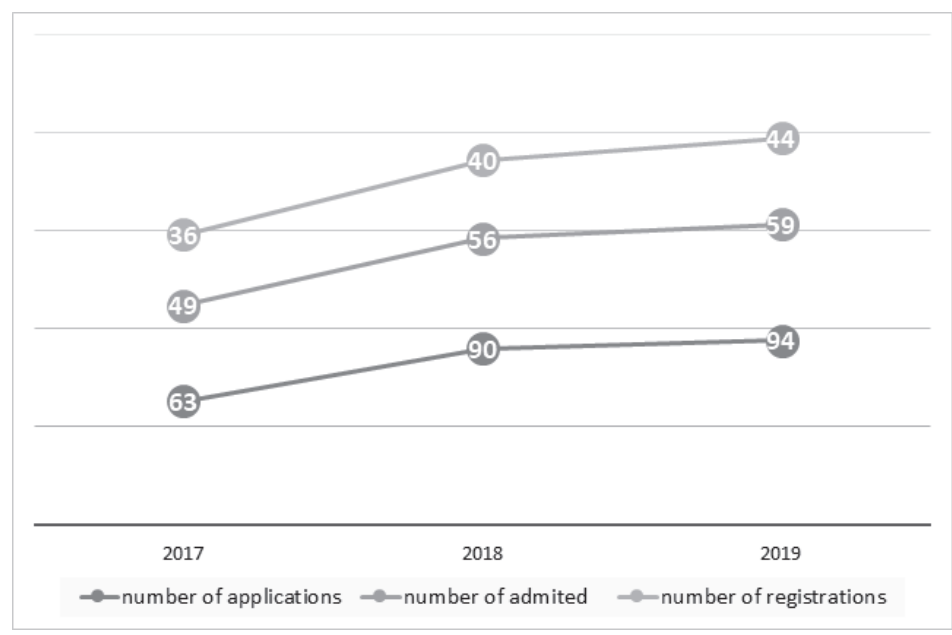

Figure 5. Numbers of applications, of admissions and number of applicants for mass media studies FA UPJS in Košice (undergraduate)

The number of applicants for study in 2018 compared to 2017 significantly increased, up to $42.86 \%$. A higher number of applications in 2018 is based mainly on communication with our applicants through the newly established Facebook profile \#MaŠtu. We also observed a rising trend in this parameter for the year 2019 when the number of applications grew by $4.44 \%$ year-on-year. Thanks to these demonstrably documented numerical values (source: Study Department FA UPJS) we can conclude that the hypothesis we have established has been confirmed. By active communication on the Facebook social 
network, we have achieved a significantly higher number of applicants as well as enrolled students, at a time when the numbers of students in many other fields of study are falling.

\section{Conclusion}

The implementation of online marketing in the academic field is essential. The so-called new media are the basic communication tool that Millennials communicate with. Its advantage is that it is possible to engage students who use theoretical knowledge of traditional marketing into communication with the possibility of new media. The ideal result is when this synergy has a positive impact on the decision of potential students for the advertised field. In our case, the creation of Facebook profile also contributed to the positive result, regarding the number of students applied for our field. We should be aware of the fact Facebook metrics are created in a given time and space and are flexible. We consider Facebook and other social media as the most interactive and fastest way to reach a large number of target groups. After a short period of the implementation of the so-called Explorer (separate private and advertising content on news feed) within Facebook in some countries of Europe - including Slovakia, it has been stopped for certain time because of abundant news feeds. Another consequence was that the interest of users was extended to other social networks, or to the other forms of promotion. Social media Instagram (an American photo and video sharing social networking service owned by Facebook) holds the first place for its promotion through images. It seems that Instagram will become a number one among social networks soon. Video community was, on the other hand, given to the YouTube site. Applications and service such as Snapchat, etc. are used for immediate interaction. It is, therefore, necessary to monitor the market of all social networks and to respond immediately to changes on the market. At this time, we have added an Instagram account with the same name here to the Facebook \#MaŠtu profile.

\section{References}

[1] D. Radaković and D. Herceg, "Towards a completely extensible dynamic geometry software with metadata," Computer Languages, Systems \& Structures, vol. 52, pp. 1-20, 2018. [Online]. Available: http://www.sciencedirect.com/science/article/pii/S147784241730057X

[2] P. Kommers, "Social media for learning by means of ICT," Published by the UNESCO Institutefor Information Technologies in Education, Moscow, Russian Federation, March 2011.

[3] K. Das, S. Samanta, and M. Pal, "Study on centrality measures in social networks: a survey," Soc. Netw. Anal. Min., vol. 8, no. 13, 2018.

[4] A. Elham, A. Hamidreza, and M. Hossein, "The power of ICT-based social networks in higher education," in 4th International Conference on e-Learning and e-Teaching (ICELET 2013), Feb 2013, pp. 76-80. 
[5] J. Dostál, X. Wang, W. Steingartner, and P. Naungchalerm, "Digital intelligence - new concept in context of future school of education," in ICERI2017 Proceedings, ser. 10th annual International Conference of Education, Research and Innovation. IATED, 16-18 November, 20172017 , pp. 3706-3712. [Online]. Available: http://dx.doi.org/10.21125/iceri.2017.0997

[6] E. Tokarčíková, E. Malichová, A. Kucharčíková, and M. Ďurišová, "Importance of Technical and Business Skills for Future IT Professionals," Amfiteatru Economic, vol. 22, no. 54, pp. 567-578, 052020.

[7] P. Kossecki, Ł. Korc, and S. Kossecki, "Valuation of intellectual property Software on early stage of implementation," in 2017 IEEE 14th International Conference on Informatics. IEEE, 2017, pp. 173-178.

[8] P. Kossecki. (2020, April) What is the value of film copyrights? - An analysis of basic methods of valuation. [Online]. Available:

http://dx.doi.org/10.2139/ssrn.3580949

[9] L. Baruch, P. Kalbfleisch, C. Liberman, G. Merchant, P. Walck, G. Lugano, Z. Tai, Z. Günel, S. Scifo, H. Watson, H. K. Meyer, and Y. Hu, Social Networking: Redefining Communication in the Digital Age, ser. The Fairleigh Dickinson University Press Series in Communication Studies, A. Kurylo and T. Dumova, Eds. Fairleigh Dickinson University Press, 2016.

[10] P. Kotler and G. Armstrong, Marketing. Prague, Czech Republic: Grada, 2004.

[11] K. Teplická, W. Steingartner, and M. Matvija, Innovative didactic methods in the teaching process at universities. Technical University of Košice, 2020, (in Slovak).

[12] (2018) Number of universities and faculties. [Online]. Available: http://datacube.statistics.sk/\#!/view/en/VBD_SK_WIN/sv3023rr/v_sv3023rr_ 00_00_00_en

[13] (2018) Age distribution of the population of the sr by sex and age. [Online]. Available: http://datacube.statistics.sk/\#!/view/en/VBD_SLOVSTAT/ om2024rs/v_om2024rs_00_00_00_en

[14] D. S. Pavan and L. Vishwanath, "Correlating internet, social networks and workplace - a case of generation z students," Journal of Commerce and Management Thought, vol. 8, no. 4, 2017.

[15] J. Koníčková. (2008) What is the Z Generation? (in Slovak). [Online]. Available: https:/eduworld.sk/cd/jaroslava-konickova/325/aka-je-generacia-z

[16] M. Poláš. (2016) Generation z corners: How it communicates and what media it uses. (in Slovak). [Online]. Available: https://medialne.etrend.sk/marketing/ zakutia-generacie-z-ako-komunikuje-a-ake-media-vyuziva.html 
[17] R. Cenková, "Copywriting and SEO," in Management and manufacturing systems, J. Husár, Ed. Dubrovnik, Croatia: Technical University of Košice, 2018, pp. 18-21.

[18] R. Cenková, "Content marketing," in Management and manufacturing systems, J. Husár, Ed. Dubrovnik, Croatia: Technical University of Košice, 2018, pp. 15-17.

[19] R. Cenková, "The content and the form in public relations," in Managerial trends in the development of enterprises in globalization era, I. Košičiarová and Z. Kádeková, Eds. Slovak University of Agriculture in Nitra, Faculty of Economics and Management, 2017, pp. 544-551.

[20] M. Ditrichová. (2018) How to with (controversial) Facebook metrics? (in Slovak). [Online]. Available:

https://adma.sk/ako-na-kontroverzne-facebook-metriky/ 